\title{
Manajemen Strategi Koperasi Jasa Keuangan Mikro Syariah (KJKS) \\ Studi Kasus di Baitul Mal Wat tamwil (BMT) Syariah Sejahtera Boyolali
}

\author{
Dwi Harmoyo \\ BMT Syariah Sejahtera Boyolali \\ dwiharmoyo@ymail.com
}

\begin{abstract}
The purposes pf the research are: (1) to analyze the external factor and internal factor of KJKS BMT Syariah Sejahtera. (2) To analyze the strengthen, weaknesses, opportunity, and threat of KJKS BMT Syariah Sejahtera. (3) To formulate the alternative strategic management of KJKS BMT Syariah Sejahtera. The research uses descriptive qualitative method approach about strategy management of KJKS BMT Syariah Sejahtera with business environment analysis approach that consists of external environment and internal environtment. The external environment consists of general environtment such as: politic, economic, social, and technology (PEST) and also industrial environment. Internal environmen tcosists of oganization aspek, moneter, weaknesses, opportunity and threat (SWOT Analysis) are formulated in alternatif strategic mangement of KJKS BMT Syariah Sejahtera. The result of the research show that general environment of KJKS BMT Syariah Sejahtera shows a good enaugh prospect. Industrial environment shpws that there isi any high competition. Internal environment shows that KJKS BMT Syariah Sejahtera has three primer competitions. Based on the SWOT Analysis, shows that in SWOT - 4K quadrant, the position of KJKS BMT Syariah Sejahtera in the I quadrant in 0,09 position for strengthen-weaknesses and 2,40 for opprtunity-threat. The position shows that the alternative strategic mangement that can be done by

KJKS BMT Syariah Sejahtera is the growth strategy in corporate strategy and focus strategy in business strategy. The result of the research is aspcted useful for KJKS BMT Syariah Sejahtera and others micro syariah finance, and also for the writer.
\end{abstract}

Keywords: Strategic Management, Business Environment, SWOT Analysis. 


\begin{abstract}
Abstrak
Penelitin ini bertujuan: (1) Menganalisis faktor eksternal dan faktor internal KJKS BMT Syariah Sejahtera; (2) Menganalisis kekuatan, kelemahan, peluang dan tantangan KJKS BMT Syariah Sejahtera; (3) Merumuskan alternarif manajemen strategi KJKS BMT Syariah Sejahtera. Penelitian ini menggunakan pendekatan metode diskriptif kualitatif tentang manajemen strategi KJKS BMT Syariah Sejahtera dengan pendekatan analisis lingkungan bisnis yang meliputi lingkungan eksternal dan lingkungan internal. Lingkungan eksternal terdiri dari lingkungan unun yakni politik, ekonomi, sosial dan teknologi (PEST) serta lingkungan industri. Lingkungan internal terdiri dari aspek organisasi, keuangan, pemasaran, produk dan operasi, sumber daya manuasia dan sistem informasi manajemen. Dari analisis lingkungan bisnis akan diketahui kekuatan, kelemahan, peluang dan tantangan KJKS BMT Syariah Sejahtera. Dengan analisis kekuatan, kelemahan, peluang dan tantangan tersebut (analisis SWOT) akan dapat dirumuskan alternatif manajemen strategi KJKS BMT Syariah Sejahtera. Hasil penelitian menunjukkan bahwa lingkungan umum KJKS BMT Syariah Sejahtera memperlihatkan adanya prospek yang cukup baik. Lingkungan industri keuangan adanya persaingan yang cukup tinggi. Lingkungan internal menunjukkan bahwa KJKS BMT Syariah Sejahtera memiliki tiga syarat kompetisi inti. Berdasarkan pada analisis SWOT, menunjukkan bahwa dalam kuadran SWOT-4K, posisi KJKS BMT Syariah Sejahtera pada kuadran I di posisi 0,90 untuk kekuatan-kelemahan dan 2,40 untuk peluang-tantangan. Dengan posisi ini maka alternatif manajemen strategi yang dapat dilakukan KJKS BMT Syariah Sejahtera adalah strategi pertumbuhan pada strategi korporat dan strategi fokus pada strategi bisnis. Hasil penelitian diharapkan dapat bermanfaat bagi BMT Syariah Sejahtera maupun praktisi keungan mikro syariah lainnya, demikian juga bagi penulis.
\end{abstract}

Kata kunci: Manajemen Strategi, Lingkungan Bisnis, SWOT Analisis.

\title{
Pendahuluan
}

Perkembangan industri keuangan syariah -terutama perbankan syariah- di Indonesia saat ini tumbuh secara pesat. Saat ini telah terdapat 11 bank umum syariah (BUS), 23 unit usaha syariah (UUS) dengan total Aset sebesar Rp. 126 triliun (Republika: 11/11/2011). Dalam skala mikro hal ini diikuti pula oleh perkembangan lembaga keuangan mikro syariah dalam 
bentuk Koperasi Jasa Keuangan Syariah (KJKS), Koperasi Simpan Pinjam Syariah (KSPS) atau Unit Simpan Pinjam Syariah (USPS) yang biasanya menggunakan nama Baitul Māl wa al-Tamwl (BMT).

Dalam perjalanannya, menurut data dari Pusat Inkubasi Bisnis dan Usaha Kecil (PINBUK: 2009) tercatat lebih dari 4500 BMT yang tersebar di seluruh Indonesia. Data tersebut masih memungkinkan bertambah, karena masih banyak BMT yang beroperasi tanpa berbadan hukum atau belum tergabung dalam asosiasi BMT. Jawa Tengah merupakan wilayah subur pertumbuhan BMT, di samping Jawa Barat dan beberapa propinsi lainnya. Jumlah BMT yang telah mencapai ribuan dalam waktu 10 tahun terakhir ini menurut Karim (2009) menunjukkan kemampuannya bertahan dan berkembang dalam kondisi krisis ekonomi sekalipun.

Keberadaan lembaga keuangan mikro syariah dengan model BMT memiliki peran yang sangat strategis dalam menumbuhkan sektor riil, terutama usaha skala mikro dan kecil. Pengembangan sektor riil tersebut merupakan pengaruh dari sistem operasional BMT yang menggunakan prinsip syariah. Transaksi uang dalam syariah Islam selalu berwujud transaksi riil, sehingga pertumbuhan sektor keuangan akan selalu diikuti pula oleh pertumbuhan di sektor riil. Sedangkan dalam pengembangan sektor usaha mikro dan kecil, adalah wujud konsistensi pelayanan BMT pada sektor mikro yang selama ini kurang dapat dijangkau oleh perbankan dengan alasan efisiensi.

Sebagai Lembaga Keuangan Mikro Syariah (LKMS), BMT dapat menjadi mediator antara pemilik dana atau surplus dana untuk diberdayakan pada usaha-usaha produktif. Usaha produktif yang dimaksud dapat berupa pembiayaan jual beli (murābaḥah), sewa menyewa (ijārah), modal kerja usaha (mựāabah) dan kerjasama usaha (mushārakah). Dengan fungsi ini, BMT diharapkan dapat berperan dalam menggerakkan Usaha Mikro Kecil Menengah (UMKM).

Dengan peran strategis yang dimiliki BMT, perlu ada dukungan dari berbagai pihak agar lembaga keuangan mikro syariah BMT dapat tumbuh dan berkembang dengan baik dan berkelanjutan (sustainable). Dalam perjalanannya, banyak BMT yang eksis dan tumbuh menjadi besar, bahkan banyak BMT yang memiliki aset lebih besar dari pada BPR/BPRS. 
Meskipun demikian, tidak sedikit BMT yang berdiri mengalami kegagalan, banyak masalah, lalu bubar atau tetap berjalan tapi dalam kondisi yang tidak sehat. Bahkan pernah diberitakan kasus penyelewengan oleh oknum pengelola yang tidak bertanggungjawab. Kondisi demikian jika dibiarkan akan memperburuk citra BMT di masyarakat dan tingkat kepercayaan terhadap lembaga ini menjadi rendah.

Sebagai sistem lembaga keuangan mikro yang relatif masih baru, hal yang wajar jika BMT masih dilingkupi banyak persoalan yang menghambat pengembangan BMT di masa depan. Persoalan-persoalan itu sebagaimana yang di publikasikan oleh BMT Centre (2004) meliputi: Regulasi yang belum lengkap, keterbatasan cakupan pasar, rendahnya tingkat pemahaman masyarakat terhadap produk BMT, institusi pendukung yang belum efektif, kualitas sumber daya insani, dan tidak adanya manajemen yang baik dalam mengembangkan bisnis keuangan mikro syariah.

BMT sebagai sebuah entitas perusahaan, dalam pendiriannya pastilah juga memiliki tujuan. Tujuan pokok tersebut antara lain memperoleh keuntungan, meningkatkan nilai perusahaan dan mempertahankan kelangsungan hidupnya.

Menurut Suwarsono (1994) untuk mencapai tujuan yang telah ditetapkan, manajemen perlu memperhatikan dua faktor pokok, yakni faktor eksternal yang tidak terkontrol oleh perusahaan dan faktor internal yang sepenuhnya berada dalam kendali perusahaan.

Faktor eksternal meliputi lingkungan industri (industry environment) dan lingkungan bisnis makro (macro environment): ekonomi, politik, hukum, teknologi dan sosial budaya. Faktor internal meliputi semua jenis fungsional manajemen: pemasaran, keuangan, operasi, sumber daya manusia, penelitian dan pengembangan, sistem informasi manajemen dan budaya perusahaan. Dari faktor internal dapat diidentifikasi kekuatan (strength) dan kelemahan (weakness) perusahaan. Analisis lingkungan perusahaan inilah yang populer dengan analisis SWOT (Strength, Weakness, Opportunities, Threat).

Perusahaan akan mampu mencapai tujuan yang telah ditetapkan ketika kekuatan perusahaan melebihi kelemahan yang dimiliki. Dengan kekuatan tersebut perusahaan dapat memanfaatkan peluang dan mengantisipasi hambatan bisnisnya. Melalui analisis SWOT, dapat disimpulkan tentang 
tercapai atau tidaknya tujuan perusahaan yang telah ditetapkan, yang sesungguhnya merupakan adalah fungsi dari lingkungan makro, lingkungan industri, manajemen fungsional dan budaya perusahaan (Suwarsono: 1994).

Karena skala usahanya yang relatif masih kecil, banyak BMT yang dikelola ala kadarnya tanpa memperhatikan faktor-faktor lingkungannya guna merumuskan manjemen stratategi yang baik.

\section{Manajemen Strategi dan Tingkatannya}

Kajian mengenai manajemen strategi telah banyak dilakukan pada perusahaan-perusahaan besar baik di bidang manufaktur maupun jasa termasuk industri keuangan perbankan. Manajemen strategi pada bisnis jasa keuangan mikro syariah BMT merupakan kajian yang menarik karena bisnis ini termasuk fenomena baru yang sedang tumbuh subur.

Pengertian manajemen strategi (strategic management) menurut Dirgantoro (2001) adalah suatu proses berkesinambungan yang membuat organisasi secara keseluruhan dapat match dengan lingkungannya, atau dengan kata lain, organisasi secara keseluruhan dapat selalu responsif terhadap perubahan-perubahan di dalam lingkungannya baik yang bersifat internal maupun eksternal. Proses manajemen strategi ialah cara dengan jalan mana perencana strategi menentukan sasaran dan mengambil keputusan.

Menurut Dirgantoro (2001), strategi perusahaan dapat dibagi atau dibedakan menjadi tiga tingkatan strategi, yaitu: (1) Strategi tingkat perusahaan (Corporate Level Strategy); (2) Strategi tingkat bisnis unit (Business Unit Strategy); dan (3) Strategi tingkat fungsional (Functional Strategy).

\section{Struktur Lingkungan Bisnis}

Struktur lingkungan bisnis dapat dikelompokkan menjadi dua: lingkungan eksternal dan lingkungan internal. Adapun lingkungan eksternal meliputi lingkungan umum dan lingkungan industri. Adapun lingkungan internal meliputi 10 aspek, yaitu: (1) aspek organisasi; (2) aspek keuangan; (3) analisis rasio; (4) kesehatan bank; (5) manajemen asset dan liability; (6) 
manajemen modal; (7) aspek pemasaran; (8) aspek produksi dan operasi; (9) aspek sumber daya manusia; dan (10) aspek sistem informasi manajemen.

Lingkungan umum, yang merupakan aspek eksternal, mencakup elemen dalam masyarakat luas yang dapat mempengaruhi suatu industri dan perusahaan-perusahaan di dalamnya. Lingkungan umum ini secara langsung dan tidak langsung mempengaruhi kegiatan dan pengambilan srategi kebijakan perusahaan. Komponen atau faktor-faktor ini terdiri dari (Dirgantoro, 2001): (a) Komponen Sosial; (b) Komponen Ekonomi; (c) Komponen Politik; (d) Komponen Hukum; (e) Komponen Teknologi.

Sedangkan lingkungan industri, yang merupakan jenis kedua dari lingkungan eksternal, adalah bagian dari lingkugan eksternal yang memiliki implikasi relatif lebih spesifik dan langsung terhadap perusahaan.

Analisis lingkungan eksternal atau yang dikenal dengan analisis five forces dari Michael. E Porter, dipergunakan dalam menganalisis strategi bisnis. Terdapat 5 variabel utama yang disebut Lima Kekuatan Bersaing (Umar, 1999: 123) yakni: (a) Ancaman masuknya pendatang baru; (b) Persaingan sesama perusahaan dalam industri; (c) Ancaman dari produk atau servis pengganti; (d) Kekuatan tawar-menawar pembeli; (e) Kekuatan tawarmenawar pemasok.

Jika disederhanakan lingkungan industri sebagaimana diatas dapat digambarkan seperti pada gambar sebagai berikut :

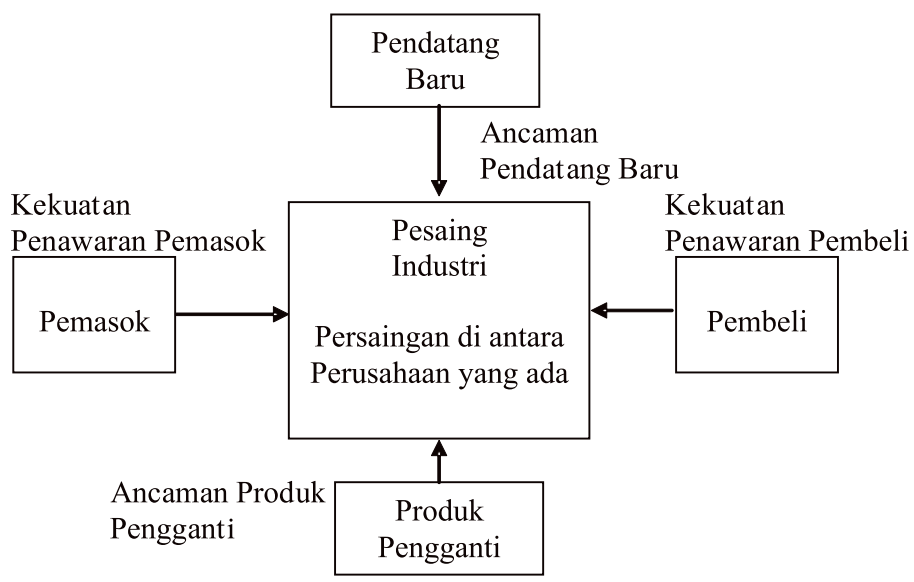

Gambar 1: Lingkungan Industri Porter 
Adapun struktur lingkungan bisnis internal adalah lingkungan yang berkaitan dengan kondisi internal yang meliputi faktor kekuatan (strength) dan kelemahan (weakness). Teknik analisis yang dilakukan pada aspek-aspek internal diharapkan untuk mendapatkan informasi yang akurat yang dapat dilakukan dengan menggunakan teknik evaluasi kinerja perusahaan dari sisi keuangan dan teknik analisis kompetensi inti (Umar, 2002).

Analisis lingkungan internal yang dikhususkan pada aspek internal perbankan yakni (Umar, 2002) :

a. Aspek organisasi, meliputi: (1) Struktur atas dasar eceran/cabang komersial; (2) Struktur atas dasar pelayanan; (3) Struktur atas dasar nasabah, dan (4) Struktur atas dasar divisi internasional yang terpusat.

b. Aspek keuangan; Yaitu dengan menganalisis rasio perbankan dan pengukuran tingkat kesehatan bank. Aspek keuangan yang penting diperhatikan adalah: (1) Manajemen Neraca; Kebijakan-kebijakan yang digulirkan pimpinan untuk mencapai sasaran tersebut adalah: Manajemen Spread dan Fee, Manajemen Overhead, Manajemen Likuiditas, Manajemen Modal, dan Manajemen Pajak.

c. Aspek pemasaran.

Disesuaikan dengan prinsip bauran pemasaran yang terdiri atas aspek produk, promosi, place dan pricing.

d. Aspek produksi dan operasi.

Aspek produksi dan operasi pada sektor perbankan lebih kepada produkproduk bank dan sistem penyampaian.

e. Aspek sumber daya manusia.

Kualitas, sikap dan perilaku SDM perbankan sangat dipengaruhi oleh perkembangan sosial, politik, kebudayaan, dan lain-lain. Oleh karena itu, kebijakan SDM terpengaruh oleh faktor-faktor eksternal, antara lain berupa perkembangan pendidikan, jumlah penawaran tenaga kerja, perkembangan sosial, perburuhan, adat, agama, budaya, dan sistem nilai masyrakat lainnya. Sedangkan faktor internal SDM akan dipengaruhi oleh manajemen SDM yang terdiri dari tiga fungsi utama, yakni fungsi manajerial, fungsi operasional dan fungsi ketiga yaitu kedudukan SDM dalam rangka pencapaian tujuan organisasi perusahaan secara terpadu. 
f. Aspek sistem informasi manajemen.

Sistem informasi perbankan dibutuhkan khususnya dalam hal pengambilan keputusan manajemen. Kemampuan yang dimiliki oleh perusahaan merupakan kompetensi inti perusahaan. Kompetensi inti ini harus diolah dan digunakan dengan baik untuk meningkatkan pangsa pasar dan meraih peluang-peluang karena kompetensi dan profesionalisme merupakan jantung dari setiap kegiatan bila ingin berhasil (Umar, 2002).

Menurut Umar (2002), kompetensi inti adalah kegiatan yang benar-benar memberikan kontribusi bagi kejayaan perusahaan dalam jangka panjang. Kompetensi dapat dikatakan sebagai kompetensi inti apabila memiliki tiga syarat sebagai berikut (Umar, 2002): (1) Nilai bagi pelanggan (Customer Value); (2) Diferensiasi bersaing (Competitor Differentiation); (3) Dapat diperluas (Extendability).

\section{Formulasi Strategi}

Ada empat macam formulasi strategi, yaitu: formulasi strategi induk, formulasi strategi korporat, formulasi strategi bisnis dan formulasi strategi fungsional.

\section{Formulasi Strategi Induk (Grand Strategy)}

Formulasi strategi pertama yang harus dirumuskan adalah menentukan dan menetapkan arah perusahaan sebagai strategi induk (grand strategy) yang meliputi: (a) Merancang Visi (Startegic Architecture); yaitu istilah yang digunakan untuk menggambarkan visi. Istilah ini digunakan oleh Prahalad dan Hamel untuk menggambarkan bahwa masa depan itu tidak hanya bisa dibayangkan, tetapi harus dibangun; (b) Menentukan Misi; Menurut Widjayakusuma dan Yusanto (2003), misi merupakan pernyataan yang menjelaskan alasan pokok berdirinya organisasi dan membantu mengesahkan fungsinya dalam masyarakat atau lingkungan; (c) Menentukan Tujuan; Widjayakusuma dan Yusanto (2003) menjelaskan pula, bahwa tujuan adalah akhir perjalanan yang dicari organisasi untuk dicapai melalui eksistensi dan operasinya serta merupakan sasaran yang lebih nyata dari pernyataan misi. Beberapa hal yang harus diperhatikan dalam mengembangkan tujuan 
agar berkualitas adalah dengan formulasi SMART. Yang dimaksudkan adalah bahwa tujuan harus Spesific (sesuatu yang unique, khas), Measurable (sesuatu yang dapat diukur/kuantitatif), Attainable (sesuatu yang dapat dicapai), Realistic (sesuatu yang realistis), dan Timely basis (berorientasi waktu); (d) Strategic Intent; Yaitu memberikan semangat dan antusiasme dalam meraih visi, misi dan tujuan. Menurut Hamel dan Prahalad, hal ini yang disebut strategic intent. Strategic intent merupakan faktor yang dapat membangkitkan energi emosional dan intelektual untuk semakin mencintai aktivitas atau pekerjaan

\section{Formulasi Strategi Korporat}

Strategi korporat dirumuskan manajemen tingkat atas dan dirancang untuk mencapai tujuan perusahaan secara keseluruhan. Strategi pada tingkat korporat sebagai strategi umum (general strategy) yang terdiri:

a. Concentration Strategy

Concentration strategy adalah strategi di mana perusahaan memfokuskan diri kepada satu lini bisnis saja. Strategi ini dilakukan dengan maksud untuk memperoleh keunggulan bersaing dengan mengkonsentrasikan seluruh sumber daya pada satu bidang atau produk saja sehingga lebih terfokus dan terspesialisasi dengan harapan akan diperoleh tingkat efisiensi yang tinggi.

b. Stability Strategy

Perusahaan yang menerapkan strategi ini memfokuskan dirinya kepada lini bisnis yang sudah ada atau yang selama ini sudah digeluti dan usaha dilakukan untuk mempertahankannya. Strategi ini biasanya diterapkan oleh perusahaan yang berada pada industri dengan tingkat pertumbuhan yang rendah atau pada industri yang sudah tidak tumbuh (jenuh).

c. Growth Strategy

Pada umumnya perusahaan akan berusaha secara maksimal untuk mengejar pertumbuhan/growth, dan kalau bisa maka tujuannya adalah untuk mencapai pertumbuhan yang terus menerus/berkelanjutan atau yang biasa disebut dengan sustainable growth. Pertumbuhan yang diinginkan tersebut bisa dalam hal penjualan, keuntungan/profit, pangsa 
pasar dan lain-lain. Strategi pertumbuhan (growth strategy) sering kali dikatakan sebagai strategi pengembangan perusahaan, yang memiliki pedoman strategi sebagai pilihan generik. Pedoman ini dapat berupa pengambilan kembali kegiatan bisnis yang pernah dilepas, konsolidasi, penetrasi pasar, pengembangan produk, pengembangan pasar dan diversifikasi.

d. Retrenchment Strategy

Strategi yang diterapkan ketika perusahaan sudah tidak lagi bisa bersaing secara efektif.

e. Combination Strategy

Perusahaan besar yang melakukan diversifikasi umumnya menggunakan kombinasi dari beberapa strategi. Formulasi strategi bisnis yang konsisten dalam perusahaan besar dan terdiversifikasi bukanlah hal yang mudah karena beberapa tingkat strategi harus dikoordinasikan untuk mencapai tujuan organisasi secara keseluruhan.

\section{Formulasi Strategi Bisnis}

Formulasi strategi bisnis melibatkan pengambilan keputusan pada tingkat divisi atau tingkat unit bisnis. Pendekatan strategi ini adalah menggunakan pendekatan analisis kompetitif dari Michael Porter sebagaimana dalam analisis lingkungan industri. Berdasarkan analisis kompetitif di atas maka Michael Porter tiga strategi yang disebutnya sebagai strategi generik (generic strategy) yang terdiri dari :

a. Strategi keunggulan biaya menyeluruh (overall cost leadership).

Cirinya adalah perusahaan lebih memperhitungkan pesaing daripada pelanggan dengan cara memfokuskan harga jual produk yang murah, sehingga biaya produksi, promosi maupun riset dapat ditekan, bila perlu produk yang dihasilkan hanya sekadar meniru produk dari perusahaan lain. Keunggulan biaya memerlukan konstruksi agresif dari fasilitas skala yang efisien, usaha yang giat untuk mencapai penurunan biaya karena pengalaman, pengendalian biaya dan overhead yang ketat, penghindaran pelanggan marjinal, serta meminimalkan biaya dalam bidang-bidang seperti litbang, pelayanan, armada penjualan, periklanan dan lain-lain. 
b. Strategi diferensiasi (differentiation).

Strategi ini cirinya adalah bahwa perusahaan mengambil keputusan untuk membangun persepsi pasar potensial terhadap suatu produk/jasa yang unggul agar tampak berbeda dengan produk yang lain. Dengan demikian, diharapkan calon konsumen mau membeli dengan harga mahal karena adanya perbedaan itu. Strategi ini lebih difokuskan kepada penciptaan sesuatu yang baru yang dirasakan oleh keseluruhan industri sebagai hal yang unik. Pendekatan untuk melakukan diferensiasi dapat bermacammacam bentuknya seperti citra rancangan atau merek, teknologi, karakteristik khusus, pelayanan pelanggan, jaringan penyalur, atau dimensi-dimensi lain. Diferensiasi, jika tercapai merupakan strategi yang baik untuk menghasilkan laba di atas rata-rata dalam suatu industri karena strategi ini menciptakan suasana yang aman untuk mengatasi kelima kekuatan persaingan.

c. Strategi fokus (focus)

Cirinya adalah perusahaan mengkonsentrasikan pada pangsa pasar yang kecil untuk menghindar dari pesaing dengan menggunakan strategi kepemimpinan biaya menyeluruh atau diferensiasi. Strategi fokus dibangun untuk melayani target tertentu secara baik, dan semua kebijakan fungsional dikembangkan atas dasar pemikiran ini. Strategi ini didasarkan pada pemikiran bahwa perusahaan dengan demikian akan mampu melayani target strategisnya yang sempit secara lebih efektif dan efisien dibandingkan pesaing yang bersaing lebih luas. Perusahaan yang memilih strategi fokus secara potensial juga dapat menghasilkan laba di atas rata-rata untuk industrinya.

\section{Formulasi Strategi Fungsional}

Strategi fungsional merupakan strategi di berbagai bidang fungsional sebagai penjabaran dari strategi bisnis perusahaan. Bidang-bidang fungsional yang penting biasanya terdiri dari pemasaran, keuangan, operasi, sumber daya manusia, termasuk penelitian dan pengembangan. Dari strategi fungsional kemudian akan menjadi acuan dalam menusun program kerja pada bidang bersangkutan. 


\section{Analisis Internal dan Eksternal KJKS BMT SS Boyolali}

Dari teori di atas, analisis internal dan eksternal KJKS BMT Syariah Sejahtera dapat dipaparkan sebagai berikut:

\section{Tabel 1: Internal dan Eksternal Analisis}

\begin{tabular}{|c|c|c|c|c|c|}
\hline \multicolumn{6}{|c|}{ INTERNAL ANALISIS } \\
\hline & Faktor Strategis Internal & Bobot & Rating & Skor & \multirow[t]{2}{*}{ Keterangan } \\
\hline \multicolumn{2}{|r|}{ Kekuatan } & & & & \\
\hline 1 & $\begin{array}{l}\text { Kondisi keuangan BMT } \\
\text { Syariah Sejahtera } \\
\text { menunjukkan prestasi yang } \\
\text { menggembirakan tercermin dari } \\
\text { kinerja keuangan selama } 4 \\
\text { tahun pertama, }\end{array}$ & 0,15 & 5 & 0,60 & $\begin{array}{l}\text { Prestasi di REALITA I } \\
\text { adalah modal besar untuk } \\
\text { memaksimalkan } \\
\text { pertumbuhan yang optimis } \\
\text { di masa depan }\end{array}$ \\
\hline 2 & $\begin{array}{l}\text { Kinerja BMT Syariah Sejahtera } \\
\text { yang ditunjukan dengan } \\
\text { peningkatan pertumbuhan } \\
\text { volume usaha yang } \\
\text { menunjukkan semakin solidnya } \\
\text { manajemen BMT Syariah } \\
\text { Sejahtera }\end{array}$ & 0,20 & 7 & 1,40 & $\begin{array}{l}\text { Dengan aset Rp.6 Milyar } \\
\text { akhir tahun } 2010 \text { dituntut } \\
\text { untuk peningkatan } \\
\text { kapasitas, dan tahun } 2011 \\
\text { merupakan peletakan } \\
\text { konsep kelembagaan. }\end{array}$ \\
\hline 3 & $\begin{array}{l}\text { Dukungan dari pemilik modal } \\
\text { yang ditunjukkan dengan } \\
\text { peningkatan yang besar }\end{array}$ & 0,15 & 8 & 1,20 & $\begin{array}{l}\text { Pemilik adalah seluruh } \\
\text { anggota yang telah setor } \\
\text { SPK, SP dan SW. }\end{array}$ \\
\hline 4 & $\begin{array}{l}\text { Pasar yang dibidik oleh BMT } \\
\text { Syariah Sejahtera merupakan } \\
\text { captive market, yakni pangsa } \\
\text { pasar yang benar-benar } \\
\text { dikuasai oleh BMT Syariah } \\
\text { Sejahtera. Dalam kaitan ini, } \\
\text { meskipun muncul pesaing baru } \\
\text { yang menawarkan produk } \\
\text { sejenis, pihak anggota tidak } \\
\text { tergerak untuk mengalihkan } \\
\text { dananya ke produk baru } \\
\text { tersebut. }\end{array}$ & 0,20 & 7 & 1,40 & $\begin{array}{l}\text { Pasar konkrit dan instansi- } \\
\text { instansi keislaman telah ada } \\
\text { ikatan yang baik dengan } \\
\text { BMT Syariah Sejahtera }\end{array}$ \\
\hline 5 & $\begin{array}{l}\text { Corporate image yang baik } \\
\text { dalam perkembangan usaha } \\
\text { BMT Syariah Sejahtera. }\end{array}$ & 0,15 & 7 & 1,40 & $\begin{array}{l}\text { Pengakuan lebih syari, lebih } \\
\text { cocoperatif dan lebih besar } \\
\text { bagi hasilnya. }\end{array}$ \\
\hline 6 & $\begin{array}{l}\text { Jaringan kantor yang dimiliki } \\
\text { BMT Syariah Sejahtera saat ini } \\
\text { cukup efektif dalam } \\
\text { meningkatkan market sharenya, } \\
\text { yakni dengan membuka kantor } \\
\text { cabang. }\end{array}$ & 0,15 & 5 & 0,60 & $\begin{array}{l}\text { Dengan tiga kantor cabang } \\
\text { telah memberikan kontribusi } \\
42 \% \text { Aset perusahaan. }\end{array}$ \\
\hline & Total & 1,00 & & 5,60 & \\
\hline
\end{tabular}




\begin{tabular}{|c|c|c|c|c|c|}
\hline \multicolumn{2}{|r|}{ Kelemahan } & \multirow[b]{2}{*}{0,25} & \multirow[b]{2}{*}{5} & \multirow[b]{2}{*}{1,25} & \multirow[b]{2}{*}{$\begin{array}{l}\text { Besarnya biaya operasional } \\
\text { terutama pada pengadaan } \\
\text { aktiva tetap yang besar } \\
\text { seperti gedung. }\end{array}$} \\
\hline 1 & $\begin{array}{l}\text { Biaya operasional yang masih } \\
\text { tinggi sehingga belum bisa } \\
\text { menghasilkan laba sisa hasil } \\
\text { usaha yang signifikan. }\end{array}$ & & & & \\
\hline 2 & $\begin{array}{l}\text { Sistem informasi manajemen } \\
\text { BMT Syariah Sejahtera yang } \\
\text { belum mendukung sistem } \\
\text { operasi jasa keuangan } \\
\text { sebagaimana perbankan. }\end{array}$ & 0,25 & 5 & 1,25 & $\begin{array}{l}\text { Soft ware IT sudah } \\
\text { diaplikasikan sejak tahun } \\
2007 \text {, hana fasilitas on line } \\
\text { antar cabang hingga } \\
\text { sekarang belum ada. }\end{array}$ \\
\hline 3 & $\begin{array}{l}\text { Belum adanya promosi yang } \\
\text { gencar dalam memasarkan } \\
\text { produk yang menyebabkan } \\
\text { produk-produk BMT Syariah } \\
\text { Sejahtera kurang diketahui } \\
\text { oleh masyarakat Boyolali }\end{array}$ & 0,20 & 5 & 1,00 & $\begin{array}{l}\text { Penawaran saat ini banyak } \\
\text { menggunakan strategi } \\
\text { partnership berdasarkan } \\
\text { kedekatan personal } \\
\text { marketing. }\end{array}$ \\
\hline 4 & $\begin{array}{l}\text { Keunikan dan kualitas produk- } \\
\text { produk jasa keuangan syariah } \\
\text { yang ditawarkan BMT Syariah } \\
\text { Sejahtera masih belum } \\
\text { diformulasikan dengan baik. }\end{array}$ & 0,15 & 5 & 0,60 & $\begin{array}{l}\text { Produk-produk yang telah } \\
\text { ada masih bersifat reguler } \\
\text { sebagaimana BMT yang } \\
\text { lain. }\end{array}$ \\
\hline 5 & $\begin{array}{l}\text { Ijin operasi BMT Syariah } \\
\text { Sejahtera yang hanya setingkat } \\
\text { kabupaten Boyolali saat ini } \\
\text { merupakan salah satu } \\
\text { kelemahan BMT Syariah } \\
\text { Sejahtera, karena membatasi } \\
\text { market share di luar Boyolali }\end{array}$ & 0,15 & 5 & 0,60 & $\begin{array}{l}\text { Akta pendirian KJKS BMT } \\
\text { Syariah Sejahrtera } \\
\text { menyatakan bahwa wilayah } \\
\text { operasional usaha di } \\
\text { kabupaten Boyolali. }\end{array}$ \\
\hline & Total & 1,00 & & 4,70 & \\
\hline \multicolumn{6}{|c|}{ EKSTERNAL ANALISIS } \\
\hline \multirow{2}{*}{\multicolumn{2}{|c|}{ Peluang }} & Bobot & Rating & Skor & Keterangan \\
\hline & & & & & \\
\hline 1 & $\begin{array}{l}\text { Perkembangan teknologi } \\
\text { informasi yang berkembang } \\
\text { sangat cepat mempunyai } \\
\text { dampak terhadap munculnya } \\
\text { berbagai macam produk baru } \\
\text { dalam industri keuangan dan } \\
\text { peningkatan pelayanan } \\
\text { terhadap anggota. }\end{array}$ & 0,30 & 6 & 1,80 & $\begin{array}{l}\text { Sudah ada beberapa rencana } \\
\text { inovasi produk-produk } \\
\text { dengan memanfaatkan } \\
\text { teknologi informasi }\end{array}$ \\
\hline 2 & $\begin{array}{l}\text { Kebijakan pemerintah yang } \\
\text { mendukung sektor UMKM } \\
\text { yang semakin membaik dengan } \\
\text { kebijakan anggaran disetiap } \\
\text { Departemen. }\end{array}$ & 0,25 & 7 & 1,75 & $\begin{array}{l}\text { KJKS BMT Syariah } \\
\text { Sejahtera pernah dipercaya } \\
\text { untuk mengelola dana } \\
\text { Pengembangan Usaha } \\
\text { Agribisnis Perdesaan } \\
\text { (PUAP) Kementan. }\end{array}$ \\
\hline
\end{tabular}




\begin{tabular}{|c|c|c|c|c|c|}
\hline 3 & $\begin{array}{l}\text { Semangat keberislaman } \\
\text { masyarakat merupakan potensi } \\
\text { pasar dalam periode beberapa } \\
\text { tahun mendatang memiliki } \\
\text { prospek yang sangat } \\
\text { menjanjikan bagi dunia usaha } \\
\text { keuangan mikro syariah }\end{array}$ & 0,20 & 8 & 1,60 & $\begin{array}{l}90 \% \text { penduduk adalah } \\
\text { muslim dan saast ini adalah } \\
\text { masa-masa kebanghkitan } \\
\text { umat islam untuk } \\
\text { menjalankan agamanya } \\
\text { secara kaffah. }\end{array}$ \\
\hline 4 & $\begin{array}{l}\text { Sektor UMKM yang } \\
\text { merupakan salah satu sektor } \\
\text { yang memiliki pangsa pasar } \\
\text { yang besar merupakan peluang } \\
\text { yang dapat dicermati dalam } \\
\text { pengembangan market share } \\
\text { BMT Syariah Sejahtera. }\end{array}$ & 0,25 & 8 & 2,00 & $\begin{array}{l}\text { BMT Syariah Sejahtera } \\
\text { selama ini konsentrasi pada } \\
\text { serktor UMKM } \\
\text { perdagangan dan jasa. }\end{array}$ \\
\hline & Total & 1,00 & & 7,15 & \\
\hline \multicolumn{6}{|c|}{ Ancaman } \\
\hline 1 & $\begin{array}{l}\text { Kondisi sosial, politik dan } \\
\text { ekonomi yang kurang stabil } \\
\text { mengakibatkan pengaruh yang } \\
\text { sangat kuat terutama pada } \\
\text { kebijakan dan peraturan } \\
\text { pemerintah yang berubah-ubah. }\end{array}$ & 0,15 & 5 & 0,75 & $\begin{array}{l}\text { Payung hukum koperasi } \\
\text { masih agak rumit dalam } \\
\text { menerapkan prinsip-prinsip } \\
\text { perkoperasian. }\end{array}$ \\
\hline 2 & $\begin{array}{l}\text { Kurangnya pasokan tenaga } \\
\text { kerja yang terampil dan } \\
\text { memahami dunia keuangan } \\
\text { syariah terutama mikro syariah. }\end{array}$ & 0,20 & 5 & 0,75 & $\begin{array}{l}\text { Jenjang Dewan pengawas } \\
\text { syariah strata tiga jurusan } \\
\text { syariah dan manajer telah } \\
\text { mendapat sertifikat } \\
\text { kompetensi manajer KJKS. }\end{array}$ \\
\hline 3 & $\begin{array}{l}\text { Munculnya pesaing baru yang } \\
\text { berasal dari industri yang sama, } \\
\text { yakni koperasi-koperasi simpan } \\
\text { pinjam konvensional maupun } \\
\text { syariah termasuk perbankan } \\
\text { yang ikut menggarap sektor } \\
\text { mikro. }\end{array}$ & 0,25 & 5 & 1,25 & $\begin{array}{l}\text { Di Boyolali telah muncul } \\
\text { BMT-BMT baru dan telah } \\
\text { beroperasi dalam lima tahu } \\
\text { terakhir. }\end{array}$ \\
\hline 4 & $\begin{array}{l}\text { Meningkatnya tuntutan pasar } \\
\text { terhadap peningkatan strandar } \\
\text { kualitas di bidang jasa } \\
\text { keuangan seiring dengan } \\
\text { perkembangan teknologi. } \\
\text { Ancaman yang muncul adalah } \\
\text { perkembangan teknologi } \\
\text { tersebut kurang diimbangi oleh } \\
\text { keterbatasan dan kemampuan } \\
\text { sumberdaya perusahaan }\end{array}$ & 0,20 & 5 & 1,00 & $\begin{array}{l}\text { IT merupakan sarana } \\
\text { penting lembaga keuangan } \\
\text { dan BMT Syariah Sejahtera } \\
\text { telah memiliki aplikasi IT } \\
\text { sejak } 2007 \text { dan } 2009 \text { untuk } \\
\text { kantor cabang. }\end{array}$ \\
\hline 5 & $\begin{array}{l}\text { Diberitakannya ke media } \\
\text { beberapa lembaga sejenis BMT } \\
\text { yang bermasalah akan } \\
\text { membawa dampak yang tidak } \\
\text { baik yang mengakibatkan } \\
\text { turunnya kepercayaan } \\
\text { masyarakat }\end{array}$ & 0,20 & 5 & 1,00 & $\begin{array}{l}\text { Kebanakan BMT yang } \\
\text { bermasalah adalah akibat } \\
\text { mismanajemen dan human } \\
\text { error. }\end{array}$ \\
\hline & Total & 1,00 & & 4,75 & \\
\hline
\end{tabular}


Selanjutnya berdasarkan kuantifikasi perhitungan lingkungan bisnis di atas dapat dihitung gap antara kekuatan dan kelemahan, peluang dan ancaman sebagaimana tabel berikut :

Tabel 2: Selisih Nilai Tertimbang KJKS BMT Syariah Sejahtera

\begin{tabular}{|c|c|}
\hline Nilai tertimbang kekuatan perusahaan & 5,60 \\
Nilai tertimbang kelemahan perusahaan & 4,70 \\
\hline \multicolumn{1}{|c|}{ Selisih positif } & $\mathbf{0 , 9 0}$ \\
\hline Nilai tertimbang peluang perusahaan & 7,15 \\
Nilai tertimbang ancaman perusahaan & 4,75 \\
\hline Selisih positif & $\mathbf{2 , 4 0}$ \\
\hline
\end{tabular}

Dari tabel selisih nilai tertimbang di atas, menunjukkan kondisi internal antara kekuatan dan kelemahan KJKS BMT Syariah Sejahtera menunjukkan selisih positif yakni 0,90 , demikian juga kondisi eksternal antara peluang dan ancaman KJKS BMT Syariah Sejahtera menunjukkan selisih positif yakni 2,40 .

Dengan demikian posisi KJKS BMT Syariah Sejahtera berada pada kuadran I, pada posisi 0,90 dan 2,40. Secara visual dapat ditunjukkan pada gambar berikut ini :

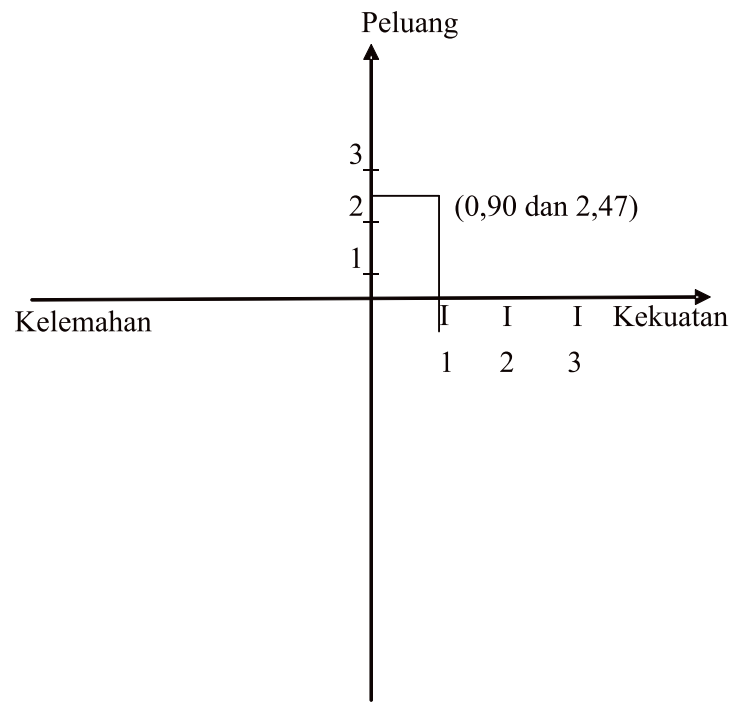

Gambar 2: Posisi KJKS BMT Syariah Sejahtera dalam Matriks SWOT-4K 


\section{Analisis Manajemen Strategi KJKS BMT SS Boyolali}

Dari penelitian ini disimpulkan bahwa dengan mengadakan analisis lingkungan bisnis yang meliputi lingkungan eksternal baik umum maupun industri dan lingkungan internal maka dapat diketahui kekuatan (strenght), kelemahan (weaknes), peluang (opportunity) dan ancaman (threats) perusahaan.

Selanjutnya dengan menganalisis SWOT ( $S W O T$ analysis) maka dapat memberikan arah bagi manajemen dalam menentukan strategi yang tepat untuk perusahaan. Dari analisis SWOT di atas dapat, ada beberapa hal yang dapat disimpulkan beberapa alternatif strategi yakni strategi korporat dan strategi bisnis KJKS BMT Syariah Sejahtera.

Adapun strategi korporat yang diambil adalah mengimplementasikan strategi pertumbuhan (Growth Strategy). Dengan strategi ini sangat dimungkinkan KJKS BMT Syariah Sejahtera untuk melakukan ekspansi, memperbesar pertumbuhan dan meraih kemajuan secara maksimal.

Alasan yang mendasari pemilihan strategi pertumbuhan ini adalah pangsa pasar KJKS BMT Syariah Sejahtera yang besar, yakni captive market dan related captive market, dalam hal ini adalah UMKM.

Sedangkan strategi bisnis yang dapat dilakukan oleh KJKS BMT Syariah Sejahtera adalah "Focus" atau fokus. Strategi ini didasarkan pada pemikiran bahwa perusahaan dengan demikian akan mampu melayani target strategisnya yang sempit secara lebih efektif dan efisien ketimbang pesaing yang bersaing lebih luas. Sebagai akibatnya perusahaan akan mencapai diferensiasi karena mampu memenuhi kebutuhan target tertentu dengan lebih baik, atau mencapai biaya yang lebih rendah dalam melayani target ini, atau bahkan mencapai kedua-duanya (Porter, 1997).

Strategi bisnis yang dapat dilakukan dengan memaksimalkan kekuatan dan peluang, serta meminimalkan dan mengantisipasi kelemahan dan tantangan KJKS BMT Syariah Sejahtera adalah sebagai berikut:

1. Menyusun rencana teknologi informasi terutama jaringan online dengan cabang dengan anggaran biaya maupun SDM yang memadai sebagai investasi masa depan. Memilih teknologi informasi yang tepat guna dan tepat sasaran dengan perhitungan biaya penyusutan dan pemeliharaan 
yang efisien. Merancang pendidikan karyawan sehingga melek teknologi. Merekrut satu orang tenaga ahli yang dapat memback up penggunaan teknologi sekaligus melatih pengelola lainnya yang terkait.

2. Mengakses program-program pemerintah dengan meningkatkan kapasitas performance lembaga sehingga dipercaya oleh pemerintah. Menghimpun dan membina kelompok usaha bersama dalam masyarakat pada setiap bidang untuk mengakses dana hibah dan program-program pemerintah.

3. Menambah perluasan jaringan dengan membuka cabang di setiap kecamatan dan mempertegas brand image sebagai lembaga milik umat Merencanakan tahapan-tahapan yang sesuai dengan perkembangan lembaga dalam rangka memperluas daerah ijin operasi padatingkat propinsi hingga nasional.

4. Menerapkan kebijakan perekrutan dan promosi karyawan yang efektif sehingga semua karyawan memahami dan bangga dengan profesinya. Merencanakan program pendidikan terpadu bagi karyawan maupun calon karyawan dengan kerjasama dengan dunia pendidikan.

5. Perlu disusun peta sosial ekonomi masyarakat untuk lebih memaksimalkan peluang pasar UMKM. Lebih fokus pada UMKM yang beresiko rendah seperti perdagangan dan jasa. Untuk sektor pertanian dan industri harus lebih hati-hati dengan perhitungan yang matang. Fokus pada segmen pasar yang dikuasai dan memaksimalkan kompetensi inti perusahaan. Memperkuat loyalitas anggota dengan strategi partnership marketing dengan memaksimalkan filosofi lembaga.

6. Membangun visi dan misi perusahaan yang fleksibel sehingga lebih mudah menyesuaikan perubahan.serta secara berkala selalu mengakses informasi lingkungan eksternal baik umum maupun industri. Membangun image dengan menerapkan Good Corporate Government (GCG) maupun God Corporate Government (GCG) yakni Religius Profesional. Melaksanakan pendidikan dan pembinaan anggota sebagai media informasi dan komunikasi BMT dengan anggotanya Dalam rangka memperkuat bergaining posisi, bersama dengan BMT lain membangun atau bergabung dalam asosiasi KJKS baik tingkat daerah maupun nasional. 


\section{Penutup}

Demikian alternatif strategi yang bisa diaplikasikan oleh KJKS BMT Syariah Sejahtera. Dalam waktu lima tahun pertama (REALITA I) KJKS BMT Syariah Sejahtera menunjukkan kinerja yang baik sebagai modal dasar untuk meraih visi, misi dan tujuan perusahaan pada masa yang akan datang.

Kinerja yang baik tersebut tentu tidak lepas dari kerangka konseptual yang telah direncanakan secara bersama-sama oleh seluruh tim pengurus dan pengelola BMT Syariah Sejahtera. Kerangka konseptual itu dapat dengan mudah ditelaah oleh setiap praktisi lapangan di manapun mereka berada, yaitu dengan analisis SWOT secara mendalam terhadap seluruh permasalahan yang ada. Namun demikian, kedalaman hasil dari analisis SWOT tergantung pada kedalaman dan ketelitian potret setiap kasus yang ada.

\section{DAFTAR PUSTAKA}

BMT Syariah Sejahtera. 2007. Standar Operasional Prosedur, Boyolali: BMT Syariah Sejahtera . 2009. Company Profile. Boyolali: BMT Syariah Sejahtera. 2010. Laporan RAT Tahun 2009. Boyolali: BMT Syariah Sejahtera. 2011. Laporan RAT Tahun 2010. Boyolali: BMT Syariah Sejahtera.

Dirgantoro, Crown. 2001. Manajemen Stratejik, Konsep, Kasus dan Implementasi. Jakarta: Grasindo.

Karim, Adiwarman A. 2009. "Investasi Sariah”, dalam Pengantar Investasi Syariah. Jakarta, PT Serambi Ilmu Semesta.

Pusat Inkubasi Bisnis Usaha Kecil (PINBUK). t.t. Pedoman Cara Pembentukan BMT. Jakarta: PINBUK.

. t.t. Pedoman Penilaian Kesehatan BMT. Baitul Māl wa al-tamwīl Balai Usaha Mandiri Terpadu, Jakarta: PINBUK.

. t.t., Peraturan Dasar \& Contoh AD-ART Baitul Māl wa al-tamwīl Balai Usaha Mandiri Terpadu, Jakarta: PINBUK.

Porter, M.E. 1997. Strategi Bersaing: Teknik Menganalisis Industri dan Pesaing. Erlangga.

Suwarsono, Muhammad. 2008. Matriks \& Skenario dalam Strategi. Yogyakarta: UPP STIM YKPN. 
Suwarsono. 1994. Manajemen Strategik, Konsep dan Kasus. Yogyakarta: UPP AMP YKPN.

Umar, Husein. 1999. Riset Strategi Perusahaan. Jakarta: PT Gramedia Pustaka Utama. . 2002. Strategic Management in Action, Jakarta: PT Gramedia Pustaka Utama.

Widjayakusuma, M.K. dan Yusanto, I. (2003). Manajemen Strategi Perspektif Islam. Jakarta: Khairul Bayan.

www.republika.co.id, diunduh pada tanggal 11 November 2011. 